\title{
16S rRNA and Omp31 Gene Based Molecular Characterization of Field Strains of $B$. melitensis from Aborted Foetus of Goats in India
}

\author{
Ajay Singh, ${ }^{1}$ Vivek Kumar Gupta, ${ }^{2}$ Amit Kumar, ${ }^{3}$ \\ Vikas Kumar Singh, ${ }^{2}$ and Shivasharanappa Nayakwadi ${ }^{2}$ \\ ${ }^{1}$ College of Biotechnology, Uttar Pradesh Pandit Deen Dayal Upadhayay Pashu Chikitsa Vigyan Vishwavidyalaya Evum \\ Go-Anusandhan Sansthan (DUVASU), Mathura 281001, India \\ ${ }^{2}$ Animal Health Division, Central Institute for Research on Goats (CIRG), Makhdoom, Mathura 281001, India \\ ${ }^{3}$ Department of Veterinary Microbiology, Uttar Pradesh Pandit Deen Dayal Upadhayay Pashu Chikitsa Vigyan Vishwavidyalaya Evum \\ Go-Anusandhan Sansthan (DUVASU), Mathura 281001, India
}

Correspondence should be addressed to Amit Kumar; balyan74@gmail.com

Received 23 August 2013; Accepted 30 September 2013

Academic Editors: A. Ludwig and A. M. Sahagún Prieto

Copyright (c) 2013 Ajay Singh et al. This is an open access article distributed under the Creative Commons Attribution License, which permits unrestricted use, distribution, and reproduction in any medium, provided the original work is properly cited.

\begin{abstract}
Brucellosis is a reemerging infectious zoonotic disease of worldwide importance. In human, it is mainly caused by Brucella melitensis, a natural pathogen for goats. In India, a large number of goats are reared in semi-intensive to intensive system within the close vicinity of human being. At present, there is no vaccination and control strategy for caprine brucellosis in the country. Thus, to formulate an effective control strategy, the status of etiological agent is essential. To cope up with these, the present study was conducted to isolate and identify the prevalent Brucella species in caprine brucellosis in India. The 30 samples (fetal membrane, fetal stomach content and vaginal swabs) collected throughout India from the aborted fetus of goats revealed the isolation of 05 isolates all belonging to Brucella melitensis biovars 3. All the isolates produced amplification products of 1412 and 720 bp in polymerase chain reaction with genus and species specific $16 \mathrm{~S}$ rRNA and omp31 gene based primers, respectively. Moreover, the amplification of omp31 gene in all the isolates confirmed the presence of immuno dominant outer membrane protein ( $31 \mathrm{kDa}$ omp) in all the field isolates of $B$. melitensis in aborted foetus of goats in India. These findings can support the development of omp31 based specific serodiagnostic test as well as vaccine for the control of caprine brucellosis in India.
\end{abstract}

\section{Introduction}

Brucellosis is an infectious zoonotic disease of worldwide importance in both animals and humans $[1,2]$ caused by microorganisms belonging to the genus Brucella, Gramnegative facultative intracellular bacteria [3-5]. It is a bacterial zoonosis of worldwide importance, and of major public health and economic significance $[4,6,7]$. There are few different species of Brucella, each with slightly different host specificity. Six species of Brucella have been identified: $B$. melitensis, B. suis, B. abortus, B. ovis, B. neotomae, and B. canis [8]. This classification is based on the animal host specificity, susceptibility to dyes, metabolic patterns, phage typing, and serological testing [9-12]. B. melitensis uses the sheep and goats as its preferred natural hosts but other animals and human being may also be infected $[13,14]$. Other species like $B$. abortus, B. suis, B. ovis, and B. neotomae mainly infect cattle, pigs, sheep, and rodents. Recently, new species were discovered: in marine mammals (B. pinnipedialis and $B$. cetacea), in the common vole Microtus tusarvalis (B. microti), and even in a breast implant (B. inopinata) [2].

Caprine brucellosis causes serious economic losses by way of abortions and stillbirths, besides being potentially hazardous to the animal handlers. Infected parturitions (normal birth or abortion) and infected males play important roles in the spread of infection in herds [2, 3, 13, 14]. Control of infection is necessary not only to reduce economic of losses but also to avoid contamination in man [15]. In India, 13.4\% 
of kids are expected to be lost due to Brucella originated abortions and stillbirth in semi-intensively managed goat herds [16]. Because of serious economic importance and medical consequences of brucellosis, especially in developing countries [1, 17], efforts have been made to prevent and control the disease through the use of vaccines $[2,18]$. The continued improvement of vaccines against $B$. melitensis is important for the control and eradication of the disease in sheep, goats, and human beings [18-20]. For that, isolation and characterization of the existing species is not only essential but also a key to the success in the form of diagnostic test or vaccine $[3,7,20-22]$. Thus, to establish the etiological agent of caprine brucellosis and to determine the presence of biotypes of Brucella spp. in caprine abortion cases in India, isolation and identification of causing agent is preliminary and essential step.

As unequivocal diagnosis is by bacteriological identifications of the causative agent [23] and for the confirmation of brucellosis, isolation is still a gold standard test either for the screening of the infection or preparing eradication programs [24]. Moreover, for further confirmation of Brucella species, various molecular methods have been developed [25-27] and most of them are based on the detection of omp31 gene in B. melitensis [28]. These outer membrane proteins (Omps) have been isolated and characterized from several species of Brucella initially for the development of subcellular vaccines [25-29]. Brucella abortus strains contain two major Omps designated as omp25 $(25-27 \mathrm{kDa})$ and omp2 or porin (36$38 \mathrm{kDa})[25,26]$. Similarly, B. melitensis contains two Omps with apparent molecular masses of $25-27 \mathrm{kDa}$ and $31-34 \mathrm{kDa}$, now designated as omp31 [28] and $28 \mathrm{kDa}$, designated as omp28 [27]. The omp31 gene of $B$. melitensis $16 \mathrm{M}$ has been cloned and expressed on the surface of E. coli [28] and was shown to protect mice model and natural host against a $B$. ovis challenge [30, 31]. Thus, there is an increasing interest worldwide on cloning and molecular characterization of omp31 gene from different strains of $B$. melitensis with the ultimate goal of suitable, safe, and effective vaccine and development of $B$. melitensis specific diagnostic test. Hence, the present study was planned to know the involvement of Brucella species and biovars with molecular characterization of omp31 gene encoding an immuno dominant outer membrane protein ( $31 \mathrm{kDa}$ omp) from field strain of B. melitensis in aborted foetus of goats in India.

\section{Materials and Methods}

2.1. Samples. Thirty samples collected from the aborted goats and fetus just after abortion (fetal membrane, fetal stomach content, and vaginal swabs) aseptically were subjected to isolation of bacteria and its molecular characterization through PCR.

2.2. Isolation and Identification of Brucella. For the isolation of Brucella, material from different sources was inoculated on sterile plates of Brucella selective agar media with hemin and vitamin $\mathrm{k}_{1}$ media (Hi Media) and incubated at $37^{\circ} \mathrm{C}$ for $48 \mathrm{~h}$. The plates were observed at every $24 \mathrm{~h}$ for the development of growth. After the growth, the colonies suspected for Brucella on the basis cultural characteristics [23] were picked up and streaked to another Brucella selective agar with hemin and vitamin $\mathrm{k}_{1}$ plates and incubated at $37^{\circ} \mathrm{C}$ for 2 days to obtain pure culture.

2.3. Cultural Characterization of Isolates. The pure cultures of the isolates examined by morphological examination were inoculated on Brucella selective agar medium, MacConkey Lactose agar (MLA) and Sheep blood agar [10]. The isolates showing characteristic colonies on Brucella selective agar medium, no growth on MacConkey Lactose agar (MLA) and nonhemolytic colonies on blood agar were maintained in Serum dextrose agar for further studies.

2.4. Morphological Characterization of Isolates. The isolates suspected for Brucella were subjected to Gram staining and Stamp's modified Ziehl-Neelsen (MZN) staining [23] for checking the purity of cultures and morphological characters. Stamp modified Ziehl-Neelsen staining method was performed with $0.4 \%$ basic fuchsin solution, followed by rapid decolouration with $0.5 \%$ acetic acid solution, and counterstaining with $1 \%$ methylene blue or malachite green solution. The smears were examined microscopically with an oil-immersion objective lens $(\times 100)$.

2.5. Biochemical Confirmation of Isolates. Pure suspected Brucella isolates, maintained in Serum dextrose agar, were analysed for their biochemical profiles for the differentiation of Brucella species on the basis of biochemical tests, namely, catalase, oxidase, urea hydrolysis, nitrate reduction tests, indole production, citrate utilization, methyl red and vogesproskauer tests as per the standard methods [23, 32].

2.6. Biotyping of Brucella Isolates. Cultures showing typical Brucella characteristics were subjected to biotyping techniques such as $\mathrm{H}_{2} \mathrm{~S}$ production, growth in the presence of thionin and basic fuchsin $(10-40 \mu \mathrm{g} / \mathrm{mL})$ dye incorporated into Tryptic soya agar at different concentrations $(1: 25,000$, $1: 50,000$, and $1: 100,000)$ from $0.1 \%$ stock solution (with distilled water), and $\mathrm{CO}_{2}$ requirement immediately after the primary isolation as well-described method [33]. Lead acetate strips were used to identify the production of $\mathrm{H}_{2} \mathrm{~S}$ during growth, and the growth test on media containing streptomycin $(2.5 \mu \mathrm{g} / \mathrm{mL})$ was performed to discriminate the isolates from vaccine strain Revl as per standard procedures $[11,12]$.

2.7. Molecular Characterization of Brucella melitensis Isolates. For molecular confirmation of these isolates, amplification of 16S rRNA and omp31 genes was performed by using Taq PCR master mix kit (Qiagen).

2.7.1. Extraction of DNA from Colonies. The isolate colonies from Serum dextrose agar were transferred on Brucella selective agar with hemin and vitamin $\mathrm{k}_{1}$ plates. Then, few colonies were picked and transferred into $2 \mathrm{~mL}$ eppendorf tube containing $1 \mathrm{~mL}$ of sterile PBS ( $\mathrm{pH}$ : 7.4). The suspension 
in PBS was centrifuged at $10,000 \mathrm{rpm}$ for $10 \mathrm{~min}$ at $10^{\circ} \mathrm{C}$. The supernatant was discarded and the pellet was used for extraction of DNA. Deoxyribonucleic acid (DNA) was isolated by using mdi kit (Advanced micro device Pvt. Ltd., India).

2.7.2. Polymerase Chain Reaction. DNA isolated from bacterial isolate colonies was used for polymerase chain reaction for the amplification of 16S rRNA and omp31 genes for the confirmatory identification of Brucella melitensis by using Taq PCR master mix kit (Qiagen). 16S rRNA gene is specific to the genus Brucella while the omp31 is a species specific gene to the Brucella melitensis $[34,35]$. For the amplification of $16 \mathrm{~S}$ rRNA gene primers, earlier described forward primer $\left(5^{\prime}-\right.$ AGAGTTTGATCCTGGCTCAG- $3^{\prime}$ ) and backward primer $\left(5^{\prime}\right.$-ACGGCTACCTTGTTACGACTT- $\left.3^{\prime}\right)$ were used [36]. Similarly, for the amplification of species specific omp31 gene, a set of forward ( $5^{\prime}$-TGACAGACTTTTTCGCCGAA-3 $\left.{ }^{\prime}\right)$ and backward ( $5^{\prime}$-TATGGATTGCAGCACCG- $\left.3^{\prime}\right)$ primers were applied [28]. The $25 \mu \mathrm{L}$ of PCR reaction was prepared with $12.5 \mu \mathrm{L}$ Taq PCR master mix $(2 \mathrm{x}) ; 1 \mu \mathrm{L}$ forward primer $(10 \mathrm{pmol} / \mu \mathrm{L}) ; 1 \mu \mathrm{L}$ reverse primer $(10 \mathrm{pmol} / \mu \mathrm{L}) ; 2 \mu \mathrm{L}$ template DNA, and $8.5 \mu \mathrm{L}$ nuclease free water. The final reaction volume of $25 \mu \mathrm{L}$ for each sample was used in thermal cycler (Techne, TC 4000). The amplification of 16S rRNA gene was conducted with initial denaturation at $95^{\circ} \mathrm{C}$ for $5 \mathrm{~min}$, denaturation at $95^{\circ} \mathrm{C}$ for $30 \mathrm{sec}$, annealing at $54^{\circ} \mathrm{C}$ for $1.5 \mathrm{~min}$, extension at $72^{\circ} \mathrm{C}, 1.5 \mathrm{~min}$, and finally the final extension at $72^{\circ} \mathrm{C}$ for $10 \mathrm{~min}$. The omp31 gene amplification was performed with initial denaturation at $95^{\circ} \mathrm{C}$ for $5 \mathrm{~min}$, denaturation at $95^{\circ} \mathrm{C}$ for $1 \mathrm{~min}$, annealing at $58^{\circ} \mathrm{C}$ for $1 \mathrm{~min}$, extension at $72^{\circ} \mathrm{C}$ for $1 \mathrm{~min}$, and finally the final extension at $72^{\circ} \mathrm{C}$ for $10 \mathrm{~min}$.

2.7.3. Quantitation and Quality Assessment of DNA of PCR Products by Agarose Gel Electrophoresis. For the electrophoresis of PCR products, $1 \%$ agarose gel was prepared in TAE buffer (Bangalore Genei). Ethidium bromide $(10 \mathrm{mg} / \mathrm{mL})$ was added to final concentration of $0.5 \mu \mathrm{g} / \mathrm{mL}$ and mixed gently prior to casting of gel. The PCR product $(8 \mu \mathrm{L})$ was mixed with $2 \mu \mathrm{L}$ of loading dye in gel apparatus (GeNei, India) and run at $70-80$ volt/cm for $40-50 \mathrm{~min}$ till the dye reached the half of the gel. The gel was photographed under the UV illuminator (Alpha Innotech). The size of the amplicon was assessed on the basis of comigration of standard DNA ladder of molecular weight in the range of 100-1000 bp and 1000-2000 bp for the amplifications of $16 \mathrm{~S}$ rRNA and omp31 genes, respectively (Banglore Genei).

\section{Results}

All the aborted materials collected from the cases of abortions were inoculated on Brucella selective agar plates and the isolates producing characteristic, very small, glistening and smooth, round, and pin-point colonies were further transferred on MacConkey Lactose agar (MLA) and Sheep blood agar. The isolates which did not grow on MacConkey agar (MLA) and are to be nonhemolytic on blood agar were examined for morphological characters by Gram and Modified Ziehl-Neelsen (MZN) staining. Microscopic examination of Gram-stained cultures revealed small Gram-negative coccobacilli and, on modified Ziehl-Neelsen (MZN) staining, organisms stained red against a blue background. These isolates were further assessed for the biochemical characters and the isolates were found positive for catalase, oxidase, urea hydrolysis and nitrate reduction tests and negative for indole production, citrate utilization, and methyl red, and vogesproskauer tests were suggestive of Brucella species (Table 1).

Thus, on the basis of cultural, morphological, and biochemical characteristics, five isolates were identified as Brucella species. For the conventional diagnosis of Brucella species, all the isolates were differentiated phenotypically into species and partially to biovars using parameters such as $\mathrm{CO}_{2}$ requirement, $\mathrm{H}_{2} \mathrm{~S}$ production, and growth on media plates containing thionin and basic fuchsin $(10-40 \mu \mathrm{g} / \mathrm{mL})$ dye incorporated into Tryptic soya agar at three different concentrations $(1: 25,000,1: 50,000$, and $1: 100,000)$. The growth of all the 5 isolates on media with thionin at only $40 \mu \mathrm{g} / \mathrm{mL}(1: 25,000)$ concentration and basic fuchsin at all concentrations suggested these isolates as Brucella melitensis biovar 3 (Table 1). For the confirmation of genus and species when DNA of these isolates were subjected to 16S rRNA and omp31 gene amplification for identification and characterization, an amplified product of about 1412 bp (Figure 1) and $720 \mathrm{bp}$ (Figure 2) size was found in all the 5 isolates on agarose gel electrophoresis.

\section{Discussion}

All the 5 isolates obtained from the cases of aborted fetus were initially confirmed by the cultural, morphological, and biochemical tests as Brucella species [10, 23, 32]. These 5 isolates revealed the presence of Brucella organism on Brucella selective agar medium with the development of characteristic colonies similar to the earlier reports [10]. These findings are also in the concurrence to the reports of isolation of Brucella melitensis in 25 cases in the Thrace Region [37]. All the isolates revealed morphological characters similar to previous findings [23] with biochemical tests in concurrence with the findings of other studies [23, 32]. For morphological characterization Gram staining and modified Ziehl-Neelsen (MZN) staining [23] and for the differentiation of Brucella species on the basis of biochemical tests, different tests, namely, catalase, oxidase, urea hydrolysis, nitrate reduction tests, indole production, citrate utilization, methyl red, and voges-proskauer tests (Table 1) were applied as per the method recommended earlier [32]. Similar to the earlier reports [32], all the Brucella isolates were found positive for catalase, oxidase, urea hydrolysis, and nitrate reduction tests and negative for indole production, citrate utilization, methyl red, and voges-proskauer tests (Table 1) revealing them to be Brucella species. Thus, on the basis of cultural, morphological, and biochemical characteristics, the organisms were identified as Brucella species [23, 32].

The isolates were further differentiated phenotypically into species and partially to biovars using parameters such 
TABLE 1: Species and biovar differentiation of the species of the genus Brucella isolates.

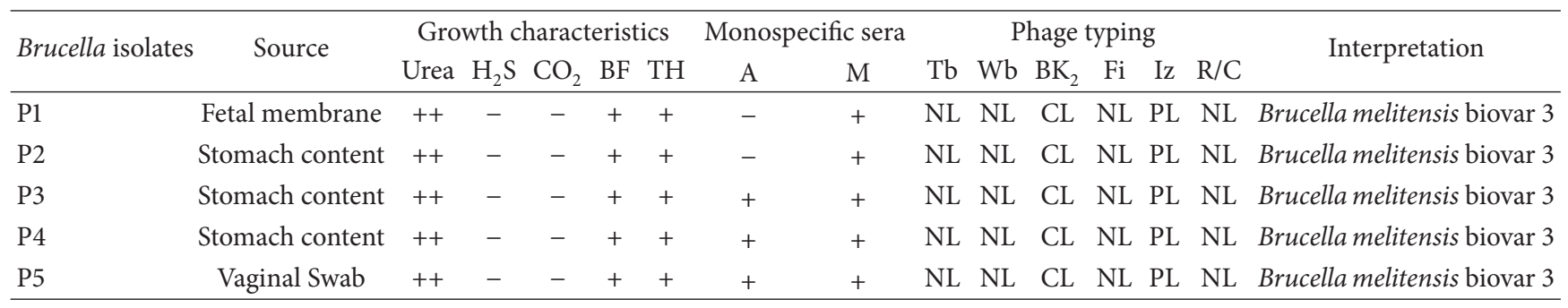

BF: basic fuchsin at $20 \mu \mathrm{L} / \mathrm{mL}(1 / 50,000 \mathrm{w} / \mathrm{v})$, TH: thionin at $20 \mu \mathrm{L} / \mathrm{mL}$ (1/50,000 w/v), CL: confluent lysis, PL: partial lysis, NL: no lysis.

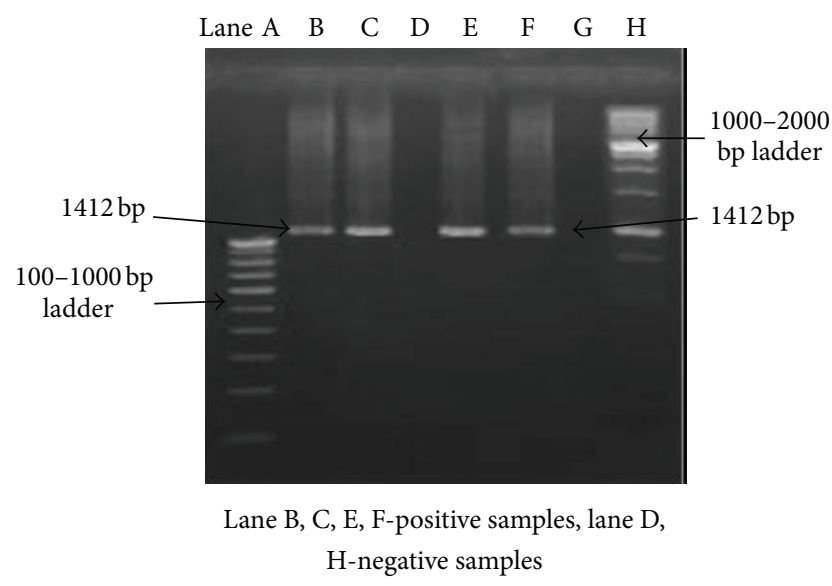

FIgUre 1: Amplification of genus Brucella specific 16S rRNA gene.

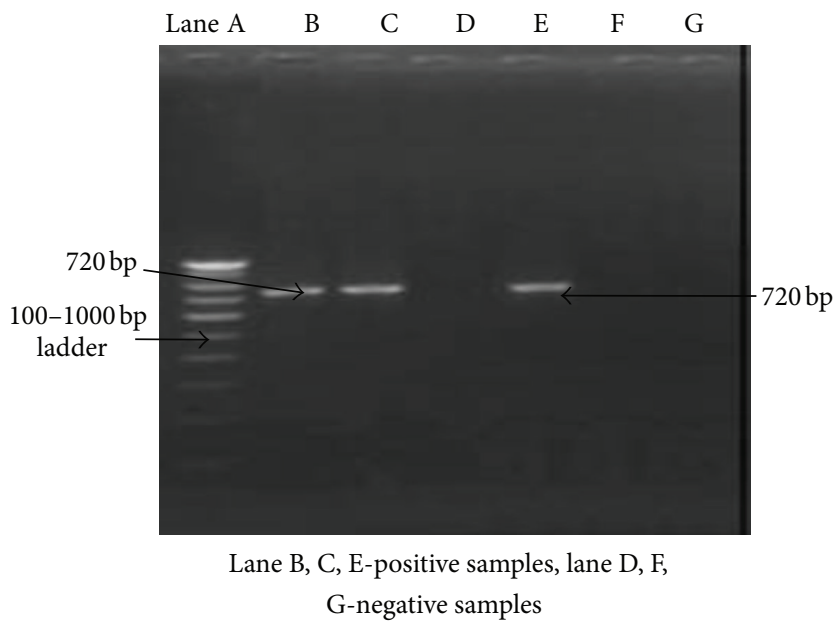

FIgURE 2: Amplification of Brucella melitensis species specific omp31 gene.

as $\mathrm{CO}_{2}$ requirement, $\mathrm{H}_{2} \mathrm{~S}$ production, and growth on media plates containing thionin and basic fuchsin dyes at three different concentrations (Table 1) [11, 12, 23, 33]. Accordingly, Brucella species grown on Tryptic soy agar media containing both thionin and basic fuchsin dyes at concentration of $40 \mu \mathrm{g} / \mathrm{mL}(1: 25,000), 20 \mu \mathrm{g} / \mathrm{mL}(1: 50,000)$, and $10 \mu \mathrm{g} / \mathrm{mL}(1: 100,000)$ have been taken as Brucella melitensis, whereas isolates with no growth at all concentrations in both the cases (thionin and basic fuchsin) were considered as Brucella melitensis biovars 2 and those grown on media with thionin at only $40 \mu \mathrm{g} / \mathrm{mL}(1: 25,000)$ concentration and basic fuchsin at all concentrations have been considered as Brucella melitensis biovar 3 (Table 1) [11, 12, 32]. These findings suggested all the isolates as Brucella melitensis biovar 3 and are in agreement with the earlier reports $[3,9,10]$. However, in earlier reports [37], 25 cases of biotypes 1 and 3 of biotype 2 among $29 \mathrm{~B}$. melitensis isolates were observed. Whereas, in about $78 \mathrm{~B}$. melitensis isolates, collected from various parts of Turkey, 69 and 9 isolates were identified as biotype 3 and biotype 1, respectively [11, 12]. Thus, Brucella melitensis biovar 3 is mainly responsible for the clinical form of brucellosis in goats and leads to abortions and other clinical signs.

The molecular approaches appeared to be faster and more sensitive than traditional bacteriological tests $[8,38-$ 40]. The 16S rRNA component of $30 \mathrm{~S}$ small subunit of prokaryotic ribosomes contains hyper-variable regions that provide species specific signature sequences useful for bacterial identification, so 16S rRNA gene can be used as the diagnostic target in the PCR for confirmatory identification of Brucella melitensis. In this study, we have primarily focused on the applicability of $16 \mathrm{~S}$ rRNA gene as a rapid confirmatory identification tool for Brucella genus as per the procedure adopted earlier [36]. The extracted DNA was PCR amplified using Brucella genus specific primers [36]. A PCR product of about $1412 \mathrm{bp}$ size of $16 \mathrm{~S}$ rRNA from all the isolates of B. melitensis was obtained (Figure 1). It confirmed that all the isolates belong to genus Brucella. The advantage of this method is that results can be obtained within 1 day as compared to 7 days by traditional microbiological testing. Previous work on other bacteria has indicated that differences in $16 \mathrm{~S}$ rRNA gene sequences may be useful for subtyping or for the differentiation of virulent subtypes from nonvirulent subtypes [41, 42]. Low variability in the $16 \mathrm{~S}$ rRNA locus has been noted as an impediment in using $16 \mathrm{~S}$ rRNA gene sequencing to discriminate at the species level [43]. In recent studies of other biothreat, select agents have indicated that even subtle differences in the $16 \mathrm{~S}$ rRNA gene sequence may be used for differentiating and identifying closely related species, which are often cross-reactive in biochemical identification systems commonly used in diagnostic laboratories [42, 44].

A multiplex system has been developed that is sensitive for Brucella spp. and is able to differentiate between $B$. melitensis and B. abortus [45]. However, discrepant results were observed with some B. abortus isolates. So far, none 
of these assays have been accepted for common use in diagnostic laboratories. Moreover, only a few studies in the literature $[13,14,46-48]$, however, address direct detection of Brucella melitensis in clinical specimens of goat origin. In the present study, a PCR based assay for the rapid and specific laboratory diagnosis of Brucella melitensis directly from tissue and blood using specific primers for the PCR amplification of a $720 \mathrm{bp}$ region on the sequence encoding the $31 \mathrm{kDa}$ immunogenic B. melitensis protein (omp31) [13,14] was applied for the confirmation of Brucella melitensis from genomic DNA with species specific primers [28]. All the isolates produced an amplified product size of about $720 \mathrm{bp}$ (Figure 2). Thus, all the isolates obtained from the cases of abortion in goats belong to $B$. melitensis as PCR amplification of omp31 gene $(720 \mathrm{bp})$ from previously extracted genomic DNA using specific oligonucleotide primers [49] confirmed the presence of this gene in B. melitensis and its absence in $B$. abortus $[3,22,50-54]$. These findings are in agreement with others which reported B. melitensis from such cases of sheep and goat abortions [11, 12,37]. Moreover, the amplification of omp31 gene confirms presence of immuno dominant outer membrane protein ( $31 \mathrm{kDa} \mathrm{omp})$ in all the field isolates of $B$. melitensis in aborted foetus of goats in India.

\section{Conclusions}

Brucella melitensis is mainly responsible for the brucellosis in goats and also transmission of infection to human being. For the control of the Brucella melitensis, effective diagnosis and vaccination are required and all these can only be decided after epidemiological studies including isolation of etiological agents from the clinical cases to establish prevalent species and biovars. A country like India with huge goat population being reared in the close vicinity of human is always on the edge of Brucella zoonoses. In such scenario, the findings of the present study that Brucella melitensis biovars 3 are the most prevalent strain in country with well-established immuno dominant outer membrane protein $(31 \mathrm{kDa}$ omp) can be a milestone for the development of effective diagnostic as well as prophylactic agent to eradicate the disease.

\section{Conflict of Interests}

The authors of the paper do not have a direct financial relation that might lead to a conflict of interests for any of the authors.

\section{Acknowledgments}

The authors are thankful to the Director of Central Institute for Research on Goats (CIRG), Makhdoom, Mathura, India, the Dean of College of Biotechnology, and Vice Chancellor of UP Pt. Deen Dayal Uphadhaya Veterinary University \& Gau Anusandhan Sansthan (DUVASU), Mathura, for providing the requisite facilities and support to carry out this investigation.

\section{References}

[1] B. G. Mantur and S. K. Amarnath, "Brucellosis in India-a review," Journal of Biosciences, vol. 33, no. 4, pp. 539-547, 2008.

[2] K. Manish, P. Chand, C. Rajesh, R. Teena, and K. Sunil, "Brucellosis: an updated review of the disease," Indian Journal of Animal Sciences, vol. 83, no. 1, pp. 3-16, 2013.

[3] SCAHAW, the European's Scientific Committee on Animal Health and Animal Welfare, "Brucellosis in sheep and Goats (Brucella melitensis)," A report of the Scientific Committee on Animal Health and Animal Welfare, European Commission, 2001.

[4] G. Pappas, P. Papadimitriou, N. Akritidis, L. Christou, and E. V. Tsianos, "The new global map of human brucellosis," Lancet Infectious Diseases, vol. 6, no. 2, pp. 91-99, 2006.

[5] L. Bounaadja, D. Albert, B. Chénais et al., "Real-time PCR for identification of Brucella spp.: a comparative study of IS711, bcsp31 and per target genes," Veterinary Microbiology, vol. 137, no. 1-2, pp. 156-164, 2009.

[6] J. Godfroid, A. Cloeckaert, J.-P. Liautard et al., "From the discovery of the Malta fever's agent to the discovery of a marine mammal reservoir, brucellosis has continuously been a reemerging zoonosis," Veterinary Research, vol. 36, no. 3, pp. 313326, 2005.

[7] H. C. Scholz, Z. Hubalek, I. Sedláček et al., "Brucella microti sp. nov., isolated from the common vole Microtus arvalis," International Journal of Systematic and Evolutionary Microbiology, vol. 58, no. 2, pp. 375-382, 2008.

[8] B. J. Bricker and S. M. Halling, "Differentiation of Brucella abortus bv. 1, 2, and 4, Brucella melitensis, Brucella ovis, and Brucella suis bv. 1 by PCR," Journal of Clinical Microbiology, vol. 32, no. 11, pp. 2660-2666, 1994.

[9] W. J. Morgan, "The use of the thionin blue sensitivity test in the examination of Brucella," Journal of General Microbiology, vol. 25, pp. 135-139, 1961.

[10] M. J. Corbel and W. J. B. Morgan, "Genus Brucella Myeyer and Shaw 1920, 173 Al," in Bergey's Manual of Systematic Bacteriology, J. G. Holt, Ed., vol. 1, pp. 377-388, Williams and Wilkins, Baltimore, Md, USA, 1984.

[11] S. Erdelling and A. Sen, "Isolation and biotypingof Brucella species in aborted sheep foetuses," Pendik Veterinary Microbiology, vol. 31, pp. 31-42, 2000.

[12] J. A. Stack and A. P. MacMillan, Identification and Biotyping of Brucella Spp, FAO/WHO Collaborating Centre for Reference and Research on Brucellosis. Central Veterinary Laboratory, 2003.

[13] V. K. Gupta, D. K. Verma, P. K. Rout, S. V. Singh, and V. S. Vihan, "Polymerase chain reaction (PCR) for detection of Brucella melitensis in goat milk," Small Ruminant Research, vol. 65, no. 1-2, pp. 79-84, 2006.

[14] V. K. Gupta, R. Kumari, D. K. Verma, K. Singh, S. V. Singh, and V. S. Vihan, "Detection of Brucella melitensis from goat tissues employing PCR," Indian Journal of Animal Sciences, vol. 76, no. 10, pp. 793-795, 2006.

[15] K. Dhama, S. Chakraborty, S. Kappor et al., "One world, one health-veterinary perspectives," Advances in Animal and Veterinary Sciences, vol. 1, no. 1, pp. 5-13, 2013.

[16] S. V. Singh, N. Singh, M. P. Singh, H. Shankar, and D. D. Lalwani, "Occurrence of abortions and seroprevalence of brucellosis in goats and sheep," Small Ruminant Research, vol. 14, no. 2, pp. 161-165, 1994. 
[17] P. Chaudhuri, R. Prasad, V. Kumar, and A. G. Basavarajappa, "Recombinant OMP28 antigen-based indirect ELISA for serodiagnosis of bovine brucellosis," Molecular and Cellular Probes, vol. 24, no. 3, pp. 142-145, 2010.

[18] V. K. Gupta, P. K. Rout, and V. S. Vihan, "Induction of immune response in mice with a DNA vaccine encoding outer membrane protein (omp31) of Brucella melitensis 16M," Research in Veterinary Science, vol. 82, no. 3, pp. 305-313, 2007.

[19] R. A. Bowden, S. M. Estein, M. S. Zygmunt, G. Dubray, and A. Cloeckaert, "Identification of protective outer membrane antigens of Brucella ovis by passive immunization of mice with monoclonal antibodies," Microbes and Infection, vol. 2, no. 5, pp. 481-488, 2000.

[20] B. Y. Kaltungo, S. N. A. Saidu, A. K. B. Sackey, and H. M. Kazeem, "Serological evidence of brucellosis in goats in Kaduna North Senatorial District of Kaduna State, Nigeria," ISRN Veterinary Science, vol. 2013, Article ID 963673, 6 pages, 2013.

[21] A. Kumar, N. C. Srivastava, and V. P. Singh, "Rapid identification of M. agalactiae and M. bovis by immuno binding assay," Indian Journal of Comparative Microbiology Immunology and Infectious Diseases, vol. 23, no. 2, pp. 161-163, 2002.

[22] A. M. Whatmore, "Current understanding of the genetic diversity of Brucella, an expanding genus of zoonotic pathogens," Infection, Genetics and Evolution, vol. 9, no. 6, pp. 1168-1184, 2009.

[23] G. G. Alton, L. M. Jones, R. D. Angus, and J. M. Verger, Techniques for the Brucellosis Laboratory, Institute National de la Recherche Agronomique, Paris, France, 1988.

[24] B. J. Bricker, "Diagnostic strategies used for the identification of Brucella," Veterinary Microbiology, vol. 90, no. 1-4, pp. 433-434, 2002.

[25] B. A. Sowa, K. A. Kelly, T. A. Ficht, M. Frey, and L. G. Adams, "SDS-soluble and peptidoglycan-bound proteins in the outer membrane-peptidoglycan complex of Brucella abortus," Veterinary Microbiology, vol. 27, no. 3-4, pp. 351-369, 1991.

[26] A. Cloeckaert, H. S.-A. Debbarh, N. Vizcaíno, E. Saman, G. Dubray, and M. S. Zygmunt, "Cloning, nucleotide sequence, and expression of the Brucella melitensis bp26 gene coding for a protein immunogenic in infected sheep," FEMS Microbiology Letters, vol. 140, no. 2-3, pp. 139-144, 1996.

[27] L. E. Lindler, T. L. Hadfield, B. D. Tall et al., "Cloning of a Brucella melitensis group 3 antigen gene encoding Omp28, a protein recognized by the humoral immune response during human brucellosis," Infection and Immunity, vol. 64, no. 7, pp. 2490-2499, 1996.

[28] N. Vizcaíno, A. Cloeckaert, M. S. Zygmunt, and G. Dubray, "Cloning, nucleotide sequence, and expression of the Brucella melitensis omp31 gene coding for an immunogenic major outer membrane protein," Infection and Immunity, vol. 64, no. 9, pp. 3744-3751, 1996.

[29] N. Vizcaíno, A. Cloeckaert, G. Dubray, and M. S. Zygmunt, "Cloning, nucleotide sequence, and expression of the gene coding for a ribosome releasing factor-homologous protein of Brucella melitensis," Infection and Immunity, vol. 64, no. 11, pp. 4834-4837, 1996.

[30] S. M. Estein, J. Cassataro, N. Vizcaíno, M. S. Zygmunt, A. Cloeckaert, and R. A. Bowden, "The recombinant Omp31 from Brucella melitensis alone or associated with rough lipopolysaccharide induces protection against Brucella ovis infection in BALB/c mice," Microbes and Infection, vol. 5, no. 2, pp. 85-93, 2003.
[31] S. M. Estein, P. C. Cheves, M. A. Fiorentino, J. Cassataro, F. A. Paolicchi, and R. A. Bowden, "Immunogenicity of recombinant Omp31 from Brucella melitensis in rams and serum bactericidal activity against B. ovis, Veterinary Microbiology, vol. 102, no. 34, pp. 203-213, 2004.

[32] E. W. Koneman, S. D. Allen, W. M. Janda, P. C. Schreckenberger, and W. C. Winn, "Brucella species," in Diagnostic Microbiology, pp. 431-436, Lippincott, Philadelphia, Pa, USA, 5th edition, 1997.

[33] I. F. Huddleson, Brucella Infections in Animals and Man, Methods of Laboratory Diagnosis, New York, NY, USA, 1934.

[34] L. Herman and H. De Ridder, "Identification of Brucella spp. by using the polymerase chain reaction," Applied and Environmental Microbiology, vol. 58, no. 6, pp. 2099-2101, 1992.

[35] C. Romero, C. Gamazo, M. Pardo, and I. Lopez-Goni, "Specific detection of Brucella DNA by PCR," Journal of Clinical Microbiology, vol. 33, no. 3, pp. 615-617, 1995.

[36] W. G. Weisburg, S. M. Barns, D. A. Pelletier, and D. J. Lane, "16S ribosomal DNA amplification for phylogenetic study," Journal of Bacteriology, vol. 173, no. 2, pp. 697-703, 1991.

[37] I. Erdogan, A. Gurel, C. Tekin, F. Uyanik, and A. Bitgel, "Tarkyabolgesindekoyun, kecivesigirlardabakeriyel abortlarintesbitivedagilimi," Pendik Veterinary Microbiology, vol. 224, pp. 23-35, 1993.

[38] M. C. Casañas, M. I. Queipo-Ortuño, A. Rodriguez-Torres, A. Orduña, J. D. Colmenero, and P. Morata, "Specificity of a polymerase chain reaction assay of a target sequence on the 31-kilodalton Brucella antigen DNA used to diagnose human brucellosis," European Journal of Clinical Microbiology and Infectious Diseases, vol. 20, no. 2, pp. 127-131, 2001.

[39] M. Da Costa, J.-P. Guillou, B. Garin-Bastuji, M. Thiébaud, and G. Dubray, "Specificity of six gene sequences for the detection of the genus Brucella by DMA amplification," Journal of Applied Bacteriology, vol. 81, no. 3, pp. 267-275, 1996.

[40] A. Kumar, A. K. Verma, and A. Rahal, "Mycoplasma bovis, a multi disease producing pathogen: an overview," Asian Journal of Animal and Veterinary Advances, vol. 6, no. 6, pp. 537-546, 2011.

[41] W. B. Nilsson, R. N. Paranjype, A. DePaola, and M. S. Strom, "Sequence polymorphism of the 16S rRNA gene of Vibrio vulnificus is a possible indicator of strain virulence," Journal of Clinical Microbiology, vol. 41, no. 1, pp. 442-446, 2003.

[42] C. T. Sacchi, A. M. Whitney, L. W. Mayer et al., "Sequencing of 16S rRNA gene: a rapid tool for identification of Bacillus anthracis," Emerging Infectious Diseases, vol. 8, no. 10, pp. 11171123, 2002.

[43] N. Vizcaíno, A. Cloeckaert, J.-M. Verger, M. Grayon, and L. Fernández-Lago, "DNA polymorphism in the genus Brucella," Microbes and Infection, vol. 2, no. 9, pp. 1089-1100, 2000.

[44] J. E. Gee, B. K. De, P. N. Levett, A. M. Whitney, R. T. Novak, and T. Popovic, "Use of $16 \mathrm{~S}$ rRNA gene sequencing for rapid confirmatory identification of Brucella isolates," Journal of Clinical Microbiology, vol. 42, no. 8, pp. 3649-3654, 2004.

[45] W. S. Probert, K. N. Schrader, N. Y. Khuong, S. L. Bystrom, and M. H. Graves, "Real-time multiplex PCR assay for detection of Brucella spp., B. abortus, and B. melitensis," Journal of Clinical Microbiology, vol. 42, no. 3, pp. 1290-1293, 2004.

[46] G. M. Matar, I. A. Khneisser, and A. M. Abdelnoor, "Rapid laboratory confirmation of human brucellosis by PCR analysis of a target sequence on the 31-kilodalton Brucella antigen DNA," Journal of Clinical Microbiology, vol. 34, no. 2, pp. 477-478, 1996. 
[47] M. I. Queipo-ortuño, P. Morata, P. Ocón, P. Manchado, and J. De Dios Colmenero, "Rapid diagnosis of human brucellosis by peripheral-blood PCR assay," Journal of Clinical Microbiology, vol. 35, no. 11, pp. 2927-2930, 1997.

[48] E. Navarro, M. A. Casao, and J. Solera, "Diagnosis of human brucellosis using PCR," Expert Review of Molecular Diagnostics, vol. 4, no. 1, pp. 115-123, 2004.

[49] S. P. Ashrafzadeh, M. Y. Sabri, M. ZamriSaad, and B. SitiKhairani, "Identification, cloning, and sequencing of a 31kilodalton Omp of Brucella melitensis," EMBL/GenBank/DDBJ databases, 2009.

[50] N. Vizcaíno, A. Cloeckaert, M. S. Zygmunt, and L. FernándezLago, "Characterization of a Brucella species 25-kilobase DNA fragment deleted from Brucella abortus reveals a large gene cluster related to the synthesis of a polysaccharide," Infection and Immunity, vol. 69, no. 11, pp. 6738-6748, 2001.

[51] N. Vizcaíno, J.-M. Verger, M. Grayon, M. S. Zygmunt, and A. Cloeckaert, "DNA polymorphism at the omp-31 locus of Brucella spp.: Evidence for a large deletion in Brucella abortus, and other species-specific markers," Microbiology, vol. 143, no. 9, pp. 2913-2921, 1997.

[52] I. Salhi, R.-A. Boigegrain, J. Machold, C. Weise, A. Cloeckaert, and B. Rouot, "Characterization of new members of the group 3 outer membrane protein family of Brucella spp," Infection and Immunity, vol. 71, no. 8, pp. 4326-4332, 2003.

[53] J. Cassataro, K. Pasquevich, L. Bruno, J. C. Wallach, C. A. Fossati, and P. C. Baldi, "Antibody reactivity to Omp31 from Brucella melitensis in human and animal infections by smooth and rough Brucellae," Clinical and Diagnostic Laboratory Immunology, vol. 11, no. 1, pp. 111-114, 2004.

[54] S. J. Cutler, A. M. Whatmore, and N. J. Commander, "Brucellosis-new aspects of an old disease," Journal of Applied Microbiology, vol. 98, no. 6, pp. 1270-1281, 2005. 

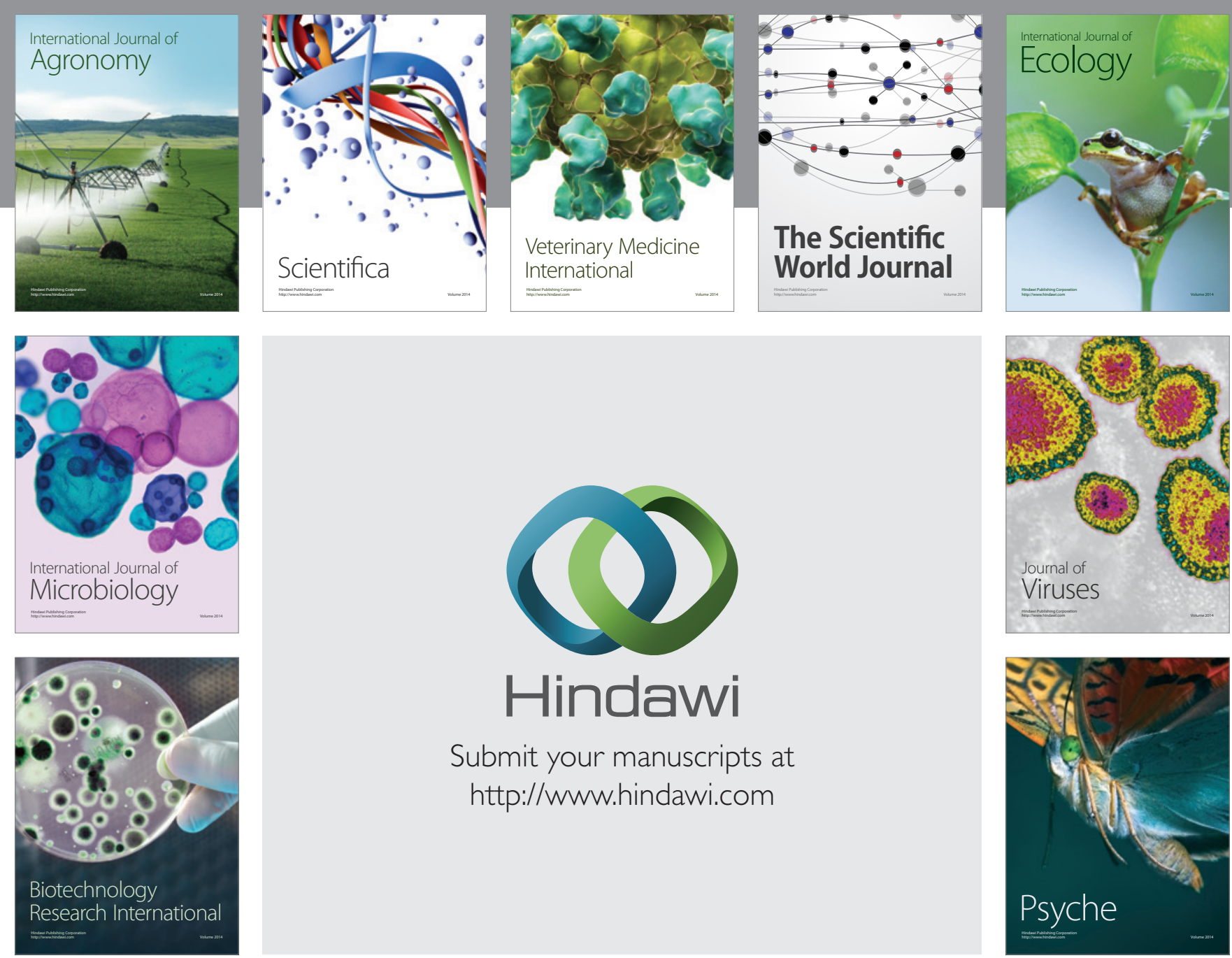

Submit your manuscripts at http://www.hindawi.com
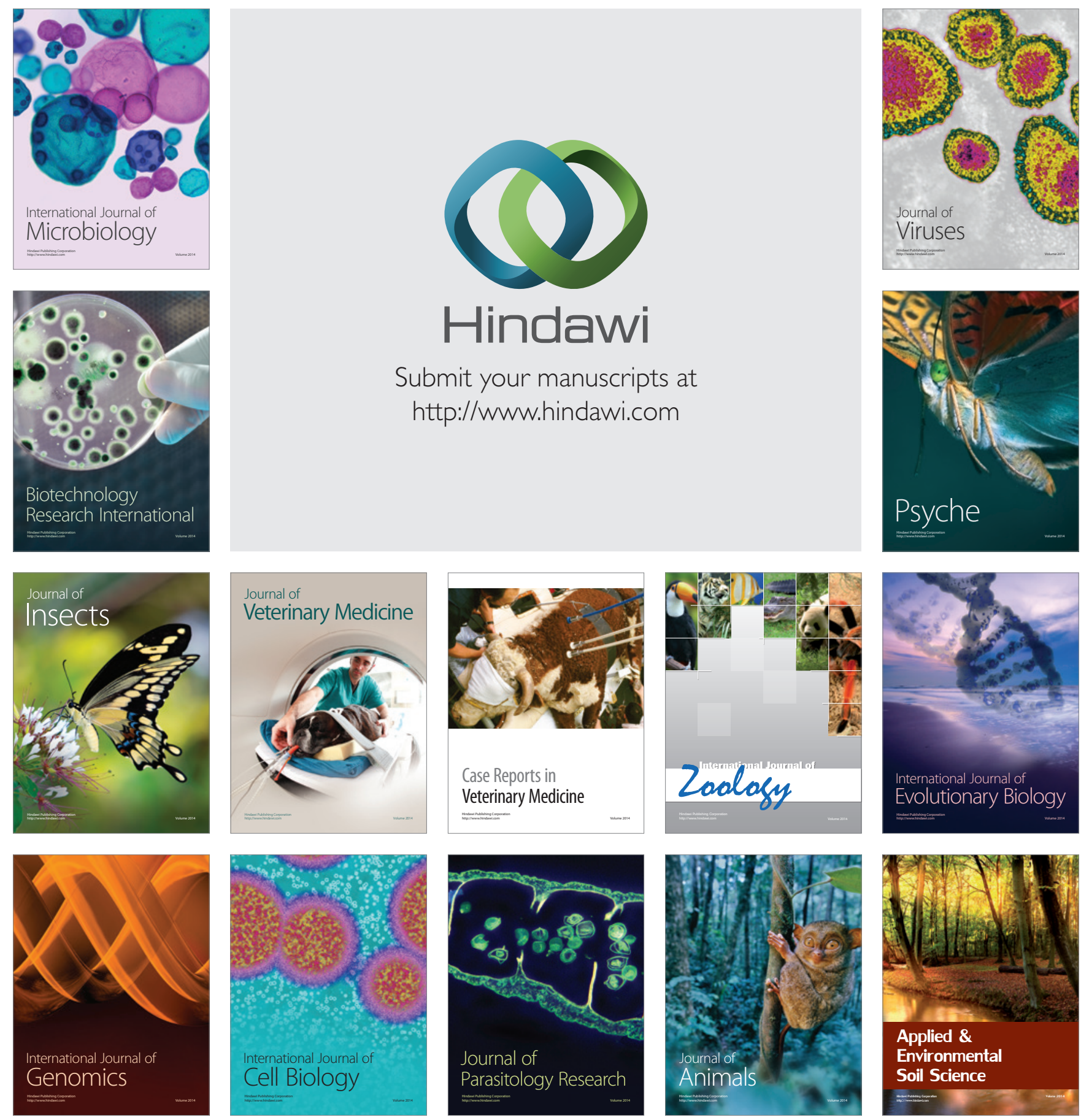